\title{
Impact of the macroeconomic determinants on the corporate profitability of companies from accommodation and food service industry in selected European countries
}

\author{
Nicole Škuláňová \\ ${ }^{1}$ Silesian University in Opava, School of Business Administration in Karvina, Univerzitní nám. 1934/3, 73340 \\ Karvina, Czech Republic;
}

\begin{abstract}
.
Every entrepreneur decides on all business matters in connection with profit. All entrepreneurs want to make a profit, and therefore profitability indicators are among the most important indicators of economic activity of the selected business unit. Profitability can be measured in many ways. The return on equity was chosen for this research, considering a number of statistically significant results. The profitability level is influenced by a number of factors that can come from both the internal and external environments of the company. This research deals with six determinants of the external environment - GDP growth rate, inflation rate, reference interest rate, unemployment rate, gross fixed capital formation and exchange rate against the euro. The impact of these factors on profitability is analyzed in eight European economies. The subject of research is the profitability of companies belonging to the accommodation and food service industry. The profitability analysis is performed at the level of seven subsectors and using the Generalized Method of Moment. The aim of the research is to find out whether selected factors influence the company's profitability or not. The research period is the period 2010 to 2018 and the researched sample contains about 24,000 companies. It is impossible to summarize the results in one sentence for the sample size, but the main conclusion is that the profitability of most subsectors is negatively affected by the reference interest rate of the economy.
\end{abstract}

Keywords: corporate profitability, GDP, inflation, interest rate, unemployment, gross fixed capital formation.

\section{Introduction}

The finance department of each company must monitor a number of indicators to control the existence of the company - such as whether it is not approaching bankruptcy, etc. There are many indicators, but some of them are of higher importance such as debt, repayment of liabilities or receivables and last but not least, profitability of the company. Almost all businesses, except non-profit companies, are established to generate and maximize profits. Thanks to profit, companies are able to expand, renew and innovate their assets. It is also an 


\section{$12^{\text {th }}$ International Conference on Modern Research in MANAGEMENT, ECONOMICS and ACCOUNTING}

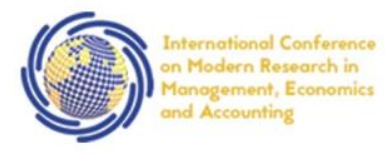

\section{4-16 May, 2021 \\ Paris, France}

important indicator from the point of view of economic theories or theories of corporate finance.

Profitability can be determined by various indicators, and as follows from the subsequent literature overview, the most common indicators include ROA, ROE, ROAA, ROAE, net interest margin, etc. Most of the indicators measure various items of the balance sheet and income statement. However, not all indicators are suitable for all research and examined sample of companies. The return on equity indicator was chosen for this research, as it showed the most statistically significant relationships among the considered indicators.

The final profitability level is influenced by many determinants, which can be divided into internal (influences from within the company) and external (influences from the company's environment - industry, economic development). This research deals with the impact of selected internal determinants at the profitability level. The aim of the research is to find out whether selected factors influence the company's profitability or not. The determinants are as follows: GDP growth rate, inflation rate, basic interest rate, unemployment rate, gross fixed capital formation and exchange rate. Companies of eight selected economies of Central and Eastern Europe and belonging to the accommodation and food service sector are the subject of this research.

A major benefit of the research is the expansion of existing knowledge in this area, as subsequent literature overview shows there are not many previous studies; most of them are devoted to banking and tourism. Previous studies also lack some of the selected determinants - such as the exchange rate and the unemployment rate. The knowledge will be expanded at the level of the issue, selected determinants, industry and economies. Furthermore, all enterprises of selected economies, industries and periods having the relevant database available are analyzed. In total, about 24,000 companies are analyzed. Details of the analysis, in which the industry is examined by seven subindustries, become the beneficial as well because the factors' impact on profitability can be seen in more detailed way than in the case the industry would have been analyzed as a whole.

This research is organized as follows. Section 1 outlines earlier studies on the factors of the corporate profitability. Section 2 presents the research methodology, variables and provides a description of the industry and examined economies. Section 3 describes the results of the analysis of variable dependencies. Section 4 presents the conclusions.

\section{Literature Overview}

This chapter deals with an overview of previous studies on the issue. As mentioned in the introduction, most of these studies examined the effects of selected determinants at the profitability level in companies belonging to banking and tourism. Despite the fact this research deals with a different sector, it is necessary to consider the findings of previous studies, in which only three of the six determinants selected by us appear - economic development, inflation rate and interest rate. It follows that assumptions will be made for these three determinants on the basis of previous studies, and assumptions will be made for 


\section{$12^{\text {th }}$ International Conference on Modern Research in}

\section{MANAGEMENT, ECONOMICS and ACCOUNTING}

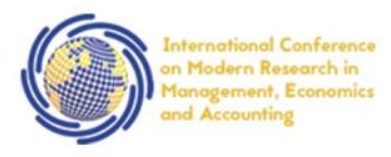

\section{4-16 May, 2021 \\ Paris, France}

the remaining three determinants (unemployment rate, gross fixed capital formation, exchange rate) on a discretionary basis. A total of 29 studies were found for this issue.

The first determinant is the development of the economy in the form of GDP growth. This determinant was included in almost all studies. The vast majority of studies revealed a positive impact of economic development on the profitability level. This means that if the economy is doing well, companies' profits usually increase as a result of rising household disposable income, which demands for more products or services being offered by companies. A positive impact can be found in the studies of Bourke (1989) for European, Australian and American banks, Molyneux and Thornton (1992) for European banks, Claessens, DemirgüçKunt and Huizinga (1998) for banking industry in 80 countries, Demirgüç-Kunt and Huizinga (1998) for commercial banks from 29 countries, Bikker and $\mathrm{Hu}$ (2002) for banks from 26 OECD countries, Bashir (2003) for Islamic banking industry, Athanasoglou, Brissimis and Delis (2008) for Greek banks, Albertazii and Gambacorta (2009) for countries form euro area nad Anglo-Saxon countries, Flamini, McDonald and Schumacher (2009) for African commercial banks, Aliaga-Diaz and Olivero (2010) for American banks, Pervan, Pervan and Guadagnino (2010) for Croatina commercial banks, Dietrich and Wanzenried (2011) for Swiss commercial banks, Ćurak, Poposki and Pepur (2012) for Macedonian banking industry, Tan and Floros (2012) for Chinese banks, Akotey, Sackey and Amoah (2013) for Ghanaian life insurance companies, Gaganis, Hasan and Pasiouras (2013) for insurance comapanies from 52 countries, Košak and Čok (2013) for banking industry in selected European countries, Mirzaei, Moore and Liu (2013) for bank from emerging economies and advanced economies, Dietrich and Wanzenried (2014) for commercial banking from 118 countries, Almeida and Divino (2015) for Brazilian banking industry, Djalilov and Piesse (2016) for commercial banks from transition countries, Saona (2016) for banking in Latin America countries, Zuidberg (2017) for American, European, Canadian, British, Australian and New Zealand airports, Chouikh and Blagui (2017) for Tunisian banks, Martins, Serra and Stevenson (2019) for American, German, British real estate banking, Vera-Gilves et al. (2020) for Ecuadorian banks, Le and Ngo (2020) for banking from 23 countries, Killins (2020) for life insurance companies.

The negative impact of economic development on the profitability level was mostly revealed in studies, in which the authors divided the examined periods into pre-crisis and crisis periods. Dietrich and Wanzenried (2011) and Martins, Serra and Stevenson (2019) found out that the positive impact of economic development was throughout the pre-crisis period and the negative impact occurred during the crisis. This result tells us that banks' profits are pro-cyclical, as demand for credit increases during economic prosperity. On the contrary, the credit quality of banks deteriorates during the recession.

Other negative effects of this variable were found in the study of Tan and Floros (2012), Dietrich and Wanzenried (2014), Saona (2016), Chouikh and Blagui (2017), Zuidberg (2017) and Le and Ngo (2020). For these results, it is difficult to say why the resulting impact was negative, as in some studies, it is not possible to say which economies and societies were present in the samples. However, we can say that if economies did well, firms with increasing output would lose in profitability, as additional output (or maintaining the current relatively 
$12^{\text {th }}$ International Conference on Modern Research in

MANAGEMENT, ECONOMICS and ACCOUNTING

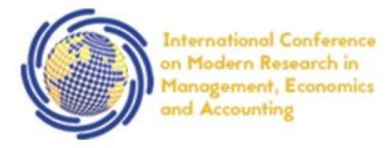

\section{4-16 May, 2021 \\ Paris, France}

high level of output) could in many cases be provided at higher operating costs. This could be one of the possible causes of the negative impact.

The impact of the inflation rate on the profitability level was also positive in most studies. The rate of inflation is linked to interest rates and indebtedness, which enables to acquire more assets that can generate greater profits. However, the impact of inflation on profitability is ambiguous depending on whether or not inflation is expected. If inflation is expected, banks can adjust their interest rates faster than their costs increase, which has a positive impact on profitability. But where inflation is not expected, costs rise faster than any interest rate adjustment, so it has a negative impact on profitability.

The positive impact was revealed in the studies of Bourke (1989), Molyneux and Thornton (1992), Claessens, Demirgüç-Kunt and Huizinga (1998), Demirgüç-Kunt and Huizinga (1998), Albertazii and Gambacorta (2009), Flamini, McDonald and Schumacher (2009), Dietrich and Wanzenried (2011), Martins, Serra and Stevenson (2019), Vera-Gilves et al. (2020) and Le and Ngo (2020). On the contrary, a negative impact was found for Martins, Serra and Stevenson (2019) during the crisis period 2007-2010, Le and Ngo (2020).

As for the impact of the interest rate on the profitability level, which, as mentioned, for the inflation rate is linked to indebtedness, the following applies: the lower the interest rate, the more companies can borrow and thus acquire more assets that can generate higher profits. A positive impact can be found in Bourke (1989), Molyneux and Thornton (1992), Claessens, Demirgüç-Kunt and Huizinga (1998), Demirgüç-Kunt and Huizinga (1998), Sufian and Chong (2008) for Philippines banks, Albertazii and Gambacorta ( 2009), Mirzaei, Moore and Liu (2013), Dietrich and Wanzenried (2014), Almeida and Divino (2015), Djalilov and Piesse (2016), Chouikh and Blagui (2017), Martins, Serra and Stevenson (2019), Vera-Gilves et al. (2020). In contrast, a negative impact was revealed in Sufian and Chong (2008), Mirzaei, Moore and Liu (2013), Dietrich and Wanzenried (2014), Djalilov and Piesse (2016), VeraGilves et al. (2020).

\section{Data and methodology}

This research is focused on the analysis of corporate profitability of companies coming from eight economies of Central and Eastern Europe. Specifically, these are the countries of the so-called extended Visegrád Group, which includes the Czech Republic (CZ), Slovakia (SK), Poland (PL), Hungary (HU), Austria (AT), Slovenia (SI), Romania (RO), and Bulgaria (BG). The inclusion of Austria, Slovenia, Romania and Bulgaria is based on the fact that economic representatives of those countries often join meetings discussing common issues and needs (e.g. territorial development, agriculture, climate policy, etc.). At the same time, the $\mathrm{V} 4+$ designation is official and includes all selected economies. For the analysis, the industry was selected, which in the NACE classification is marked as section I - Accommodation and food service activities. This sector is divided into seven groups - the subindustries that are the subject of this research. According to the mentioned classification, these are the following groups: 551 - Hotels and similar accommodation, 552 - Holiday and other short-stay accommodation, 553 - Camping grounds, recreational vehicle parks and trailer parks, 559 Other accommodation, 561 - Restaurants and mobile food service activities, 562 - Event 


\section{$12^{\text {th }}$ International Conference on Modern Research in}

\section{MANAGEMENT, ECONOMICS and ACCOUNTING}

\section{4-16 May, 2021 \\ Paris, France}

catering and other food service activities, 563 - Beverage serving activities. In terms of the number of companies in each subindustry, Restaurants and mobile food service activities (12,891 companies) and Hotels and similar accommodation (7,131 companies) are the most important subindustries within the whole industry. The number of accommodation facilities must be considerable, given that these are tourist attractions.

The accommodation and food service industry include facilities that provide customers with short-term accommodation or the preparation of food, refreshments and beverages for immediate consumption. Industry includes both accommodation and catering facilities, as the two activities are often combined in the same facility.

As far as the sample of companies examined is concerned, these are all companies that were found in the Orbis database, which provides information on medium, large and very large companies. A total of 23,991 companies are analyzed. Balance sheet and income statement information comes from the Orbis database, while macroeconomic data comes from the World Bank database (GDP, inflation, unemployment, gross fixed capital formation), individual central bank databases (reference interest rate) and the Investing.com database (exchange rate). The analysis covers the period 2010-2018.

The aim of the research is to find out whether selected factors influence the company's profitability or not. Specifically, there are six selected macroeconomic factors - the rate of GDP growth, the inflation rate, the reference interest rate, the unemployment rate, gross fixed capital formation and the exchange rate against the euro. Based on a literature review and also on the basis of our own assumptions, we expect the following relationships between determinants and profitability indicators:

- Positive relationship between profitability and economic development and gross fixed capital formation - a growing economy usually brings an increase in companies' profitability and at the same time an increase in disposable income of the remaining economic entities.

- Positive relationship between the profitability level and the inflation rate - the link to the real interest rate, which decreases due to rising inflation and thus ensures lower costs when using debt financing, the use of which may result in additional profitability.

- Negative relationship between the profitability level and the reference interest rate - the lower interest rate brings lower costs of using debt financing, the effects of which were explained by the inflation rate.

- Negative relationship between the profitability level and the unemployment rate rising unemployment should cause a decline in demand for the products of the sector, as the disposable income of individuals should decrease with the rise in unemployment.

- No assumption is made for the exchange rate. The impact of the exchange rate is analyzed only for the Czech Republic, Poland, Hungary, Bulgaria and Romania, as these countries do not have the euro as their national currency. It is well known that 


\section{$12^{\text {th }}$ International Conference on Modern Research in MANAGEMENT, ECONOMICS and ACCOUNTING}

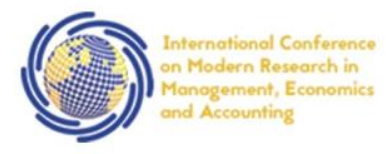

\section{4-16 May, 2021 \\ Paris, France}

a weaker currency should stimulate exporters, and a stronger currency should stimulate importers. All five countries are both exporters and importers. It is very important whether the value of exports or imports prevailed during the observed period, and therefore, it is not possible to assume relationships between variables.

\subsection{Variables}

In this section, we will analyze the variables that can be divided into endogenous and exogenous. The only endogenous variable representing corporate profitability is the return on equity with EBIT (ROE) to abstract from the divergent taxation in selected economies. The ROE indicator was selected with regard to the number of statistically significant results compared to the return on assets or return on sales, for which the analysis was also performed.

Exogenous variables are presented in the form of six selected determinants characterizing the external environment of companies. Exogenous variables are specifically in the form of the rate of GDP growth at market prices, basic interest rate of the economy (IR), inflation rate (INF), unemployment rate (UN), gross fixed capital formation (GFCF) and exchange rate to the euro. The exchange rate is included only in the analyzes of Czech, Polish, Hungarian, Bulgarian and Romanian companies. Austria, Slovakia and Slovenia have the euro as their national currency. The euro was chosen because these are European economies trading mainly in Europe and having other European countries as their main trading partners.

\subsection{Methodology}

We can use a number of methods to analyze the interdependencies between determinants and corporate profitability. Panel regression using the Generalized Method of Moments (GMM) was selected for this research, which, according to Jagannathan et al. (2002), eliminates the shortcomings of other methods and therefore found application mainly in the financial field. At the same time, panel regression is appropriate given the number of variables, economies and subindustries. Průcha (2014) further adds that, for example, the least squares method requires stationary time series, which macroeconomic data often may not meet. The GMM method does not have such a need and can work with non-stationary series, and this is the reason why it is suitable to be used for this research.

The GMM method was first described by Arellano and Bond (1991), who subsequently developed it in other studies - Arellano and Bover (1995) and Blundell and Bond (1998). The GMM method can be briefly characterized through the following points, which Roodman (2009) presents in his study. The author states that the method is suitable for shorter time series; there is a linear functional relationship and fixed individual effects are present; the endogenous variable on the left side of the equation is dynamic and depends on its delayed values; on the other hand, exogenous variables may not be strictly independent (variables may be correlated with past and present errors); the method cannot test autocorrelation and heteroskedasticity and at the same time these phenomena should not occur through observation. The method solves the endogeneity problem - the correlation between the exogenous variable and the error term, which could occur in the case the least squares method is applied. Ullah et al. (2018) states that the solution to this problem takes place through 


\section{$12^{\text {th }}$ International Conference on Modern Research in}

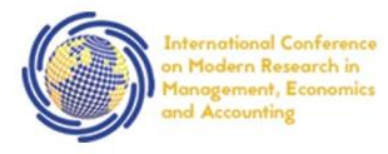

\section{4-16 May, 2021 \\ Paris, France}

internal tools (delayed value of an endogenous variable, internal transformation processes) that remove unobserved heterogeneity, simultaneity and dynamic endogeneity, which are considered sources of endogeneity.

Ullah et al. (2018) also adds that since the method cannot test for the presence of autocorrelation and heteroskedasticity, some tool is needed to determine whether the model and its results are credible. We can use several tools. The Sargan test was chosen for this research, the final value of which must exceed 0.05 in order for the model to be robust and reliable. At the same time, this means that if we change the parameters slightly, we should get the same results.

The equation of the model:

$$
R O E_{i t}=\alpha_{0}+\beta_{1}{ }^{*} R O E_{i t-1}+\beta_{2}{ }^{*} G D P_{i t}+\beta_{3}{ }^{*} I R_{i t}+\beta_{4}{ }^{*} I N F_{i t}+\beta_{5}{ }^{*} U N_{i t}+\beta_{6}{ }^{*} G F C F_{i t}+\beta_{7}{ }^{*} E X_{i t}+\varepsilon_{0} \text {; }
$$

where ROE means the return on equity, which represents the company's profitability. This variable indicates the profitability for the $\mathrm{i}$-th number of companies in a given economy in a particular sub-sector during the period $t$ (2010-2018). The right side of the equation consists of individual determinants, which are described above (GDP, IR, INF, UN, GFCF, EX). At the same time, there is a constant $\alpha$ on this side and a random component $\varepsilon$, which contains other determinants of profitability, which are not dealt with in this research, but affect its amount. The last variable on this page mentions the delayed value of the dependent variable several times. This is an annual time series lag.

\section{Results and discussion}

Figure 1 shows the results of the analysis of the determinants' influence on corporate profitability in the form of return on equity indicator. The figure includes the results for individual subindustries and economies. The research focused on eight selected economies of Central and Eastern Europe, and we see that for not a single subindustry are there results for all economies or determinants. As for the determinants, the missing determinants were not statistically significant and therefore, there is no point in dealing with them. The models of the missing economies did not meet the assumptions of the Sargan test (its values were lower than 0.05 ) and the models are not robust and the results are not reliable.

The first column contains the resulting coefficients for a variable that is not included among the selected determinants, but is an automatic part of the GMM models. This is the lagged value of the endogenous variable, i.e. corporate profitability. The resulting coefficients in all cases are very low - they reach tenths, hundredths or thousandths, so we cannot talk about a significant effect of the variable on the profitability level. It can be said that this is an indication of the direction that profitability could take in the case of larger values of the coefficient. In total, the positive impact slightly prevails, which means that if companies have achieved a certain profitability level in the past, they will continue in this trend in the future.

The remaining variables will be analyzed for individual economies, but before this analysis, the results for another variable are analyzed - gross fixed capital formation. This is provided because the resulting coefficients are also of very low values; even much lower than in the case of the lagged value of the endogenous variable. The values reach certain figures, 


\section{$12^{\text {th }}$ International Conference on Modern Research in MANAGEMENT, ECONOMICS and ACCOUNTING}

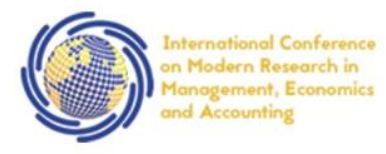

\section{4-16 May, 2021 \\ Paris, France}

which are multiplied by ten to minus the eighth and beyond. For this, there is really a very rough indication of the direction in which this variable could affect the profitability level. In summary, the negative impact very slightly prevails. Gross fixed capital formation is linked to the economic and investment cycle. In terms of the positive impact, if companies created value in the previous period, they would continue to do so in the following one. In the case of a negative link, this does not apply, in which case they would create value in the following period, but its amount would decrease.

The effects of the remaining determinants on the profitability level will be analyzed for individual subindustries and individual economies within these subindustries. Comments on the results will focus more on the variables with the greatest impact, as the analysis has shown a huge number of results that cannot be analyzed in detail.

If we look at Czech companies, we can see that, overall, the inflation rate and the unemployment rate have the greatest impact on the profitability level, followed by the reference interest rate. All impacts meet our expectations. The inflation rate has the greatest impact on the profitability level in subindustries 551 and 561, the unemployment rate has the greatest effect on the profitability level in subindustries 552 and 553, the profitability level of subindustry 563 is most affected by the interest rate. The impact of the rate can be justified by the fact that in the Czech Republic , the average inflation rate for the period under review was $1.6 \%$; such percentage could reduce the real expression of interest rates, which could thus become even lower than they were; thus, companies gained a space for debt financing, by which they could obtain cheap sources of additional financing; those finances could be invested in equity so the companies' financial background could be strengthen, which could help to increase production and, ultimately, the companies' profitability. The negative impact of the unemployment rate is obvious, as it fell from 7.3 to $2.2 \%$ during the period under review. The increase in employed population meant an increase in the disposable income that could be spent on products in the given subindustries. The negative impact of the interest rate meant cheaper debt financing costs. On average, the reference interest rate was $0.4 \%$. Adding it to the inflation rate, companies had no problem accessing other resources owners could invest in the business thus increase production.

The profitability level of Slovak companies is clearly most affected by the reference interest rate, and negatively, as we expected. The results relate to subindustries 552, 553, 561 and 562. The negative impact of the interest rate can be justified by the fact that in Slovakia, the average reference interest rate for the period under review was $0.3 \%$, which could mean very low debt financing costs, while these resources can be invested in equity and thus strengthen the companies' financial background.

The reference interest rate (negative and positive) has the greatest impact on the profitability level of Polish companies, followed by economic development and the inflation rate. The reference interest rate had both a positive (subindustry 559) and a negative impact (subindustries 552 and 561), with a negative impact prevailing. The negative impact can be explained by the fall of this rate during the period under review from 4.5 to $1.5 \%$, which resulted in cheaper debt financing, based on which resources could be purchased and invested in equity and thus the companies' financial background could be strengthen. However, on the 
$12^{\text {th }}$ International Conference on Modern Research in

MANAGEMENT, ECONOMICS and ACCOUNTING

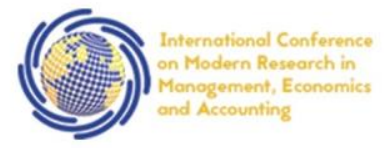

\section{4-16 May, 2021 \\ Paris, France}

other hand, the reference interest rate was high in the first half of the period, which may have had a positive impact due to, for example, the fact that companies borrowed at higher costs and could still increase their profitability. The positive impact of economic development in subindustries 551 and 553 is evident, as the Polish economy was one of the few economies, which did not experience an economic downturn during the financial crisis of $2008 / 2009$, the subsequent European debt crisis, the global slowdown in 2012/2013 and the global decline in demand at the end of the period. In the period under review, this economy grew by $3.6 \%$ year on year on average. Economic prosperity increased the disposable income of households (increase in profits) and companies (possibility of reinvesting in other assets). The negative link between the inflation rate is difficult to justify, but occurs in only one case (subindustry 563).

Figure 1: GMM model for indicator ROE

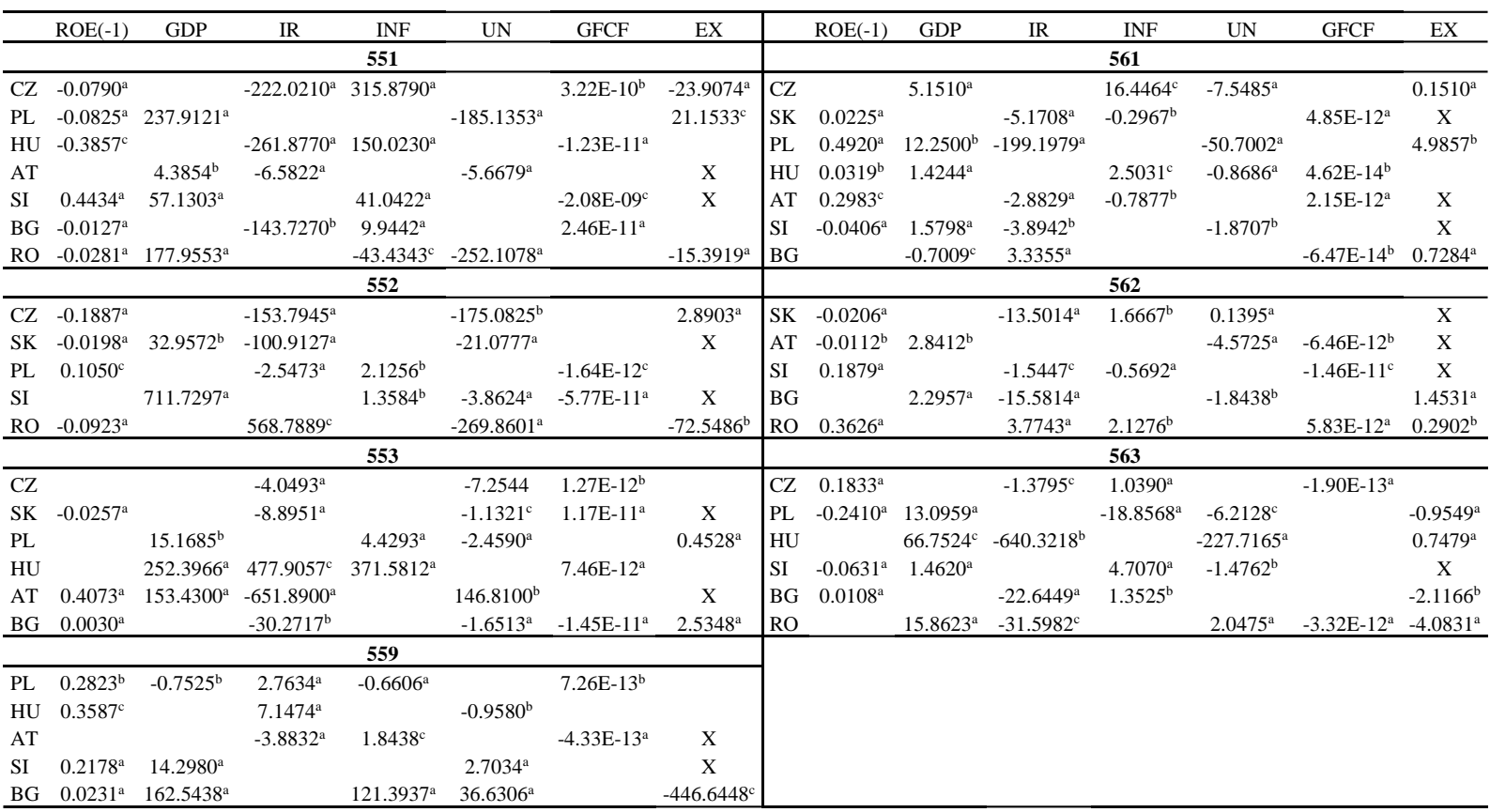

Source: author's calculations based on data from Orbis database

Symbols: ${ }^{a},{ }^{b}$ and ${ }^{c}$ indicate significance at $1 \%, 5 \%$, and $10 \%$.

As for the profitability level of Hungarian companies, subindustries 551, 553, 559 and 563 are most affected by the reference interest rate and subindustry 561 is most affected by the inflation rate. The impact of the interest rate is exactly half and half. However, the negative impact of the reference rate can be explained by a decrease in the rate during the period under review from 7.0 to $0.9 \%$, which resulted in cheaper debt financing, which may have helped to increase the equity. However, on the other hand, the interest rate was high in the first half of the period, which could have a positive impact due to, for example, the fact that companies borrowed at higher costs and could still increase their profitability. The positive impact of the inflation rate on the profitability level may have occurred due to the fact that the average inflation rate was around $2.4 \%$, which may have reduced the real expression of interest rates, 


\section{$12^{\text {th }}$ International Conference on Modern Research in MANAGEMENT, ECONOMICS and ACCOUNTING}

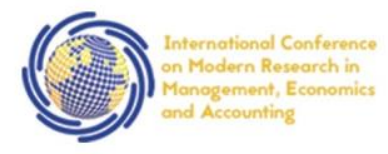

\section{4-16 May, 2021 \\ Paris, France}

which may have become even lower giving thus companies a space for debt financing that increased them profitability to be explained similarly to the interest rate itself.

The profitability level of Austrian companies is also mainly affected by the reference interest rate, and for all subindustries identified - 551, 553, 559 and 561, our assumed negative effect was also confirmed. Subindustry 562 is mainly affected by the unemployment rate, and negatively. The negative impact of the reference interest rate can be explained by the fact that the rate was $0.3 \%$ on average during the period under review, the same as in the case of Slovakia, which equally brought about the possibility of cheap indebtedness; the additional resources obtained this way could be invested in equity so that companies' financial background could become stronger. The effect of unemployment rate may be looked at from the perspective of its fluctuation moving between 4.6 and $6.0 \%$; only 3 years within the given period unemployment rose thus outweighed the decline, which meant an increase in the employed population and an increase in disposable income, which could be spent on products of the subindustries concerned.

The profitability level of Slovenian subindustries is mostly influenced by the economy development $(551,552,559)$, which is followed by the reference interest rate $(561,562)$ and the inflation rate (563). All the resulting impact meets our expectations. A positive impact of the economy development has the following explanation. At the beginning of the period, the Slovenian economy suffered from the effects of the financial crisis of 2008/2009, which had the same cause in Slovenia as in the United States - the real estate bubble and the consequent paralysis of the credit market. The Slovenian economy had not still recovered from this crisis and in 2013, it faced a banking crisis caused by an excessive risk-taking, poor management of state-owned banks and insufficient supervision. However, the Slovenian economy recovered from the crises on its own and in the second half of the considered period, it was already achieving solid growth of over $2 \%$. Ultimately, such a good growth had a positive impact on profitability. The negative impact of the interest rate can be explained in the same way as it was for Austrian and Slovak companies because Slovenia also belongs to the euro area and its monetary policy is managed by the European Central Bank. The rate was $0.3 \%$ on average during the given period, which led to the cheap indebtedness, which could be used to increase the equity. As for the positive impact of the inflation rate, the average inflation rate was around $1.2 \%$; this, as in the remaining economies, could reduce the real expression of interest rates, which could thus become even lower giving companies a space for debt financing; debt financing increased profitability through the inflow of resources into equity, which can be used to finance further development and thus increase future profits.

Bulgarian companies belong to the same category as Slovak, Hungarian, Austrian or Romanian ones, whose profitability was mainly affected by the reference interest rate. The interest rate as the main determinant of corporate profitability was confirmed in Bulgarian subindustries 551, 553, 561, 562 and 563. The impact of the reference interest rate in the mentioned subindustries was negative in almost all cases, with one exception - subindustry 561. The negative impact can be justified by the fact that the Bulgarian reference interest rate averaged $0.05 \%$ over the considered period, which clearly means very low debt for the acquisition of debt financing, based on which the equity can be increased, and thus production and profits. The profitability level of subindustry 559 was mostly affected by the exchange 


\section{$12^{\text {th }}$ International Conference on Modern Research in MANAGEMENT, ECONOMICS and ACCOUNTING}

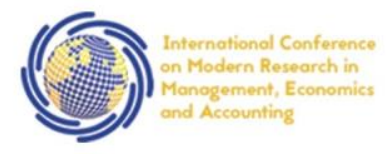

\section{4-16 May, 2021 \\ Paris, France}

rate. The impact of the exchange rate on the euro is not expected because the Bulgarian lev is practically fixed on the euro and a very small exchange rate fluctuation cannot significantly influence the amount of financial resources in conversion. Based on the fact that during 2010 2018, the volume of import prevailed each year, the Bulgarian economy is considered mainly an importer. Importers are mainly affected by the currency weakening. As for the Bulgarian currency, it was falling within six years of the given period. This fact could cause the identified negative relationship between the exchange rate and the profitability level in the given subindustry.

As mentioned in the previous paragraph, the profitability level of Romanian companies is mainly influenced by the reference interest rate, with a positive impact prevailing. This dominant impact can be found in subindustries 552, 562 and 563. Subindustry 551 is most affected by the unemployment rate. The development of the reference interest rate is similar to the Polish and Hungarian rates. This rate decreased from 6.3 to $1.8 \%$ during the period considered, and the decrease may have had a negative impact, which means a very low cost of acquiring debt financing, based on which the equity can be obtained so can production and profits. On the other hand, the interest rate was high in the first half of the period, which could have a positive impact due to, for example, the fact that companies borrowed money at higher costs and could still increase their profitability. The negative impact of the unemployment rate is justified its decrease from 7.2 to $4.2 \%$ during the observed period. As a result of such decrease, the number of employees with a salary higher than social unemployment benefits increased. Consequently, the disposable income of the population increased as well so did the demand for more production of the given subindustries.

At the end of this section, it is necessary to provide a brief summary. This part dealt with the analysis of only the largest impacts of determinants on the return on equity in individual subindustries. In 26 cases out of 41 , the impact of the reference interest rate dominates. The vast majority of these effects were negative, which means that a decrease in the rate would allow lower debt financing costs; such situation can increase companies' equity thus increase sales and profits based on increasing production. In some economies (Poland, Hungary, Romania), interest rates were high at the beginning of the examined period, but fell during it thus fulfilled our assumption of negative impact. The remaining economies then had these interest rates at almost zero throughout the examined period, thus also fulfilled our assumption of negative effect.

\section{Conclusions}

This research focused on corporate profitability and its determinants. The analyzed companies came from the accommodation and food service industry of eight selected economies of Central and Eastern Europe. Specifically, the Czech Republic, Slovakia, Poland, Hungary, Austria, Bulgaria, Slovenia, Romania were considered. The business profitability of the selected industry was analyzed at the level of seven subindustries. A total of 23,991 medium and large enterprises were analyzed. The analysis covered the period 2010-2018. The accommodation and food service industry include facilities that provide customers with short-term accommodation or the preparation of food, refreshments and beverages for 
$12^{\text {th }}$ International Conference on Modern Research in

MANAGEMENT, ECONOMICS and ACCOUNTING

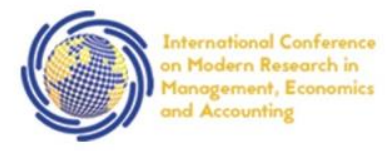

\section{4-16 May, 2021 \\ Paris, France}

immediate consumption. Industry includes both accommodation and catering facilities, as those two activities are often combined in the same facility. The aim of the research was to find out whether selected factors influence the company's profitability or not. Specifically, there were six selected macroeconomic factors - the rate of GDP growth, the inflation rate, the reference interest rate, the unemployment rate, gross fixed capital formation and the exchange rate against the euro.

Given the size of the sample examined, it is clear that there are many results. In the previous chapter, there was a detailed analysis of the most important impacts of determinants in given subindustries and individual economies presented. The main conclusion from this analysis is that the level of corporate profitability of the accommodation and food service industry is mainly influenced by the level of the reference interest rate of the given economies. The negative effect prevailed, which means that as interest rates were falling, profitability should have increased, as companies could benefit from cheaper debt financing, which could generate additional profitability by investing in equity. The resulting negative impact was expected, as the reference interest rates in the Czech, Slovak, Austrian, Slovenian and Bulgarian interest rates were very low - close to zero for most of the period under review. In Poland, Romania and Hungary, the reference interest rates were higher at the beginning of the period under review, but fell sharply during it making foreign funding more attractive.

\section{Acknowledgment}

This paper is an output of the science project SGF/8/2020 Analysis of the influence of macroeconomics variables on the profitability of companies in selected industries.

\section{References}

Akotey, J. O., Sackey, F. G. and Amoah, L. (2013). The financial performance of life insurance companies in Ghana. Journal of Risk Finance, 14(3), pp. 286-302.

Albertazzi, U. and Gambacorta, L. (2009). Bank profitability and the business cycle. Journal of Finance Stability, 5(4), pp. 393-409.

Aliaga-Diaz, R. and Olivero, M. P. (2010). The Cyclicality of Price-Cost Margins in Banking: An Empirical Analysis of its Determinants. Economic Inquiry, 49(1), pp. 26-46.

Almeida, F. and Divino, J. A. (2015). Determinants of the banking spread in the Brazilian economy: The role of micro and macroeconomic factors. International Review of Economics and Finance, 40, pp. 29-39.

Arellano, M. and Bond, S. (1991). Some Tests of Specification for Panel Data: Monte Carlo Evidence and an Application to Employment Equations. Review of Economic Studies, 58(2), pp. 277-297.

Arellano, M. and Bover, O. (1995). Another look at the instrumental variable estimation of error-components models. Journal of Econometrics, 68, pp. 29-51. 
$12^{\text {th }}$ International Conference on Modern Research in MANAGEMENT, ECONOMICS and ACCOUNTING

\section{4-16 May, 2021 \\ Paris, France}

Athanasoglou, P. P., Brissimis, S. N. and Delis, M. D. (2008). Bank-specific, industryspecific and macroeconomic determinants of bank profitability. Journal of International Financial Markets, Institutions and Money, 18(2), pp. 121-136.

Bashir, A. H. (2003). Determinants of profitability in Islamic banks: Some evidence from the Middle East. Islamic Economic Studies, 11(1), pp. 31-57.

Bikker, J. and Hu, H. (2002). Cyclical patterns in profits, provisioning and lending of banks and procyclicality of the new Basel capital requirements. Banca Nazionale del Lavoro Quarterly Review, 55(221), pp. 143-175.

Blundell, R. and Bond, S. (1998). Initial conditions and moment restrictions in dynamic panel data models. Journal of Econometrics, 87(1), pp. 115-143.

Bourke, P. (1989). Concentration and other determinants of bank profitability in Europe, North America and Australia. Journal of Banking and Finance, 13, pp. 65-79.

Chouikh, A. and Blagui, Y. (2017). The Determinants of Bank Performance: The Case of Tunisian Listed Banks. Journal of Finance and Accounting, 5(2), pp. 53-60.

Claessens, S., Demirgüç-Kunt, A. and Huizinga, H. (1998). How Does Foreign Entry Affect the Domestic Banking Market? Policy Research Working Paper No. 1918.

Ćurak, M., Poposki, K. and Pepur, S. (2012). Profitability Determinants of the Macedonian Banking Sector in Changing Environment. Procedia - Social and Behavioral Sciences, 44, pp. 406-416.

Demirgüç-Kunt, A. and Huizinga, H. (1998). Determinants of Commercial Bank Interest Margins and Profitability: Some International Evidence. The World Bank Economic Review, 13(2), pp. 379-408.

Dietrich, A. and Wanzenried, G. (2011). Determinants of bank profitability before and during the crisis: Evidence from Switzerland. Journal of International Financial Markets, Institutions and Money, 21, pp. 307-327.

Dietrich, A. and Wanzenried, G. (2014). The determinants of commercial banking profitability in low-, middle-, and high-income countries. The Quarterly Review of Economics and Finance, 54, pp. 337-354.

Djalilov, K. and Piesse, J. (2016). Determinants of bank profitability in transition countries: What matters most? Research in International Business and Finance, 38, pp. 69-82.

Flamini, V., McDonald, C. and Schumacher, L. (2009). The Determinants of Commercial Bank Profitability in Sub-Saharan Africa. IMF Working paper No. 15.

Gaganis, CH., Hasan, I. and Pasiouras, F. (2013). Efficiency and Stock Returns: Evidence from the Insurance Industry. Journal of Productivity Analysis, 40, pp. 429-442.

Goddard, J., Molyneux, P. and Wilson, J. O. S. (2004). The profitability of European banks: a cross- sectional and dynamic panel analysis. The Manchester School, 72(3), pp. 363-381. 
$12^{\text {th }}$ International Conference on Modern Research in MANAGEMENT, ECONOMICS and ACCOUNTING

\section{4-16 May, 2021 \\ Paris, France}

Jagannathan, R., Skoulakis, G. and Wang, Z. (2002). Generalized Method of Moments: Applications in Finance, Journal of Business and Economic Statistics, 20(4), pp. 470-481.

Killins, R. N. (2020). Firm-specific, industry-specific and macroeconomic factors of life insurers' profitability: Evidence from Canada. North American Journal of Economics and Finance, 51.

Košak, M. and Čok, M. (2013). Ownership Structure and Profitability of the Banking Sector: The Evidence from the SEE-6 Region. Proceedings of Rijeka Faculty of Economics, Journal of Economics and Business, 26(1), pp. 93-112.

Le, T. D. and Ngo, T. (2020). The determinants of bank profitability: A cross-country analysis. Central Bank Review, 20, pp. 65-73.

Martins, A. M., Serra, A. P. and Stevenson, S. (2019). Determinants of real estate bank profitability. Research in International Business and Finance, 49, pp. 282-300.

Mirzaei, A., Tomoe, M. and Liu, G. (2013). Does market structure matter on banks' profitability and stability? Emerging vs. advanced economies. Journal of Banking and Finance, 37, pp. 2920-2937.

Molyneux, P. and Thornton, J. (1992). Determinants of European bank profitability: A note. Journal of Banking and Finance, 16(6), pp. 1173-1178.

Pervan, M., Pervan, I. \&Guadagnino, A. (2010). Market Structure and Profitability of Croatian Commercial Banks. The Business Review, 20(1), pp. 209-216.

Průcha, I. R., 2014. Instrumental Variables/Method of Moments Estimation. In Fisher, M. M. and P. Nijkamp (Rd.), Handbook of Regional Science. Heidelberg: Springer, 1597-1617. ISBN 978-3-642-23429-3.

Roodman, D. (2009). How to do xtabond2: An introduction to difference and system GMM in Stata, The Stata Journal, 9(1), pp. 86-136.

Saona, P. (2016). Intra- and Extra-bank Determinants of Latin American Banks' Profitability. International Review of Economics and Finance, 45, pp. 197-214.

Sufian, F. and Chong, R. R. (2008). Determinants of Bank Profitability in a Developing Economy: Empirical Evidence from the Philippines. Asian Academy of Management Journal of Accounting and Finance, 4(2), pp. 91-112.

Tan, Y. A. and Floros, Ch. (2012). Bank profitability and inflation: The case of China. Journal of Economic Studies, 39(6), pp. 675-696.

Ullah, S. et al. (2018). Dealing with Endogeneity Bias: The Generalized Methods of Moments (GMM) for panel data.Industrial Marketing Management, 71, pp. 69-78.

Vera-Gilces, P. et al. (2020). A look inside banking profitability: Evidence from a dollarized emerging country. The Quarterly Review of Economics and Finance, 75, pp. 147-166. 
$12^{\text {th }}$ International Conference on Modern Research in MANAGEMENT, ECONOMICS and ACCOUNTING

\section{4-16 May, 2021}

\section{Paris, France}

Zuidberg, J. (2017). Exploring the determinants for airport profitability: Traffic characteristics, low-cost carriers, seasonality and cost efficiency. Transportation Research Part A, 101, pp. 61-72. 